\title{
EISENHÜTTENSTADT: MONITORING A SHRINKING GERMAN CITY
}

\author{
Lienhard Lötscher, Frank Howest, Ludger Basten \\ Department of Geography, Ruhr-University Bochum, 44780 Bochum, Germany \\ e-mail: lienhard.loetscher@rub.de
}

\begin{abstract}
The German Urban Commission is currently monitoring a phenomenon not entirely new: the economic and demographic shrinking of cities. As outlined during the Pretoria Conference in 2002, this process is increasingly puzzling for both urban planners and politicians, and in some regions - especially in eastern Germany - the situation is getting dramatically worse (see chapter 1). In chapter 2 and 3 of this paper we will illustrate the effects of economic and demographic shrinking, by analysing the example of the eastern German City of Eisenhüttenstadt. In chapter 4 we will outline Eisenhüttenstadt's perspectives for the future and discuss its efforts to adapt to these new challenges. The conclusion will put forward a number of theses for further discussion.
\end{abstract}

Key words: Shrinking cities, Urban decline, Urban restructuring

\section{CONTEXT}

\section{German cities in transition}

At the Pretoria Conference 2002 I mentioned that the German Urban Commission was and still is - monitoring "German cities in transition". We are focussing on two areas of interest, two challenges emerging for German cities. One is the increasing gap between the fortunes of booming or expanding and of declining or shrinking cities. The other challenge is the growing discrepancies between rich and poor within cities and the alarming consequences of social polarization and urban decay.

In the spring of 2003 the German Urban Commission met in Eisenhüttenstadt (litterally translated, the city of the ironworks), a new town established by the German Democratic Republic (GDR). We intended to gain first-hand information and insights into what is considered to be the most pressing problem in German urban development today: how to handle the impact of economic and demographic decline. This paper will introduce Eisenhüttenstadt as a city with persistant structural problems where the situation of decline is getting dramatically worse. 


\section{The rise of Eisenhüttenstadt}

Eisenhüttenstadt is a city of presently 38,000 inhabitants. It is situated on the river Oder which has been the Polish-German border since 1945 (see Fig. 1). $20 \mathrm{~km}$ to the north and south respectively lie the neighbouring cities of Frankfurt/Oder and Guben. The distance to Berlin is only $80 \mathrm{~km}$ to the west. According to the regional development plan of the federal state of Brandenburg Eisenhüttenstadt is considered an industrial middle-order centre.

Figure 1: Eisenhüttenstadt in Germany

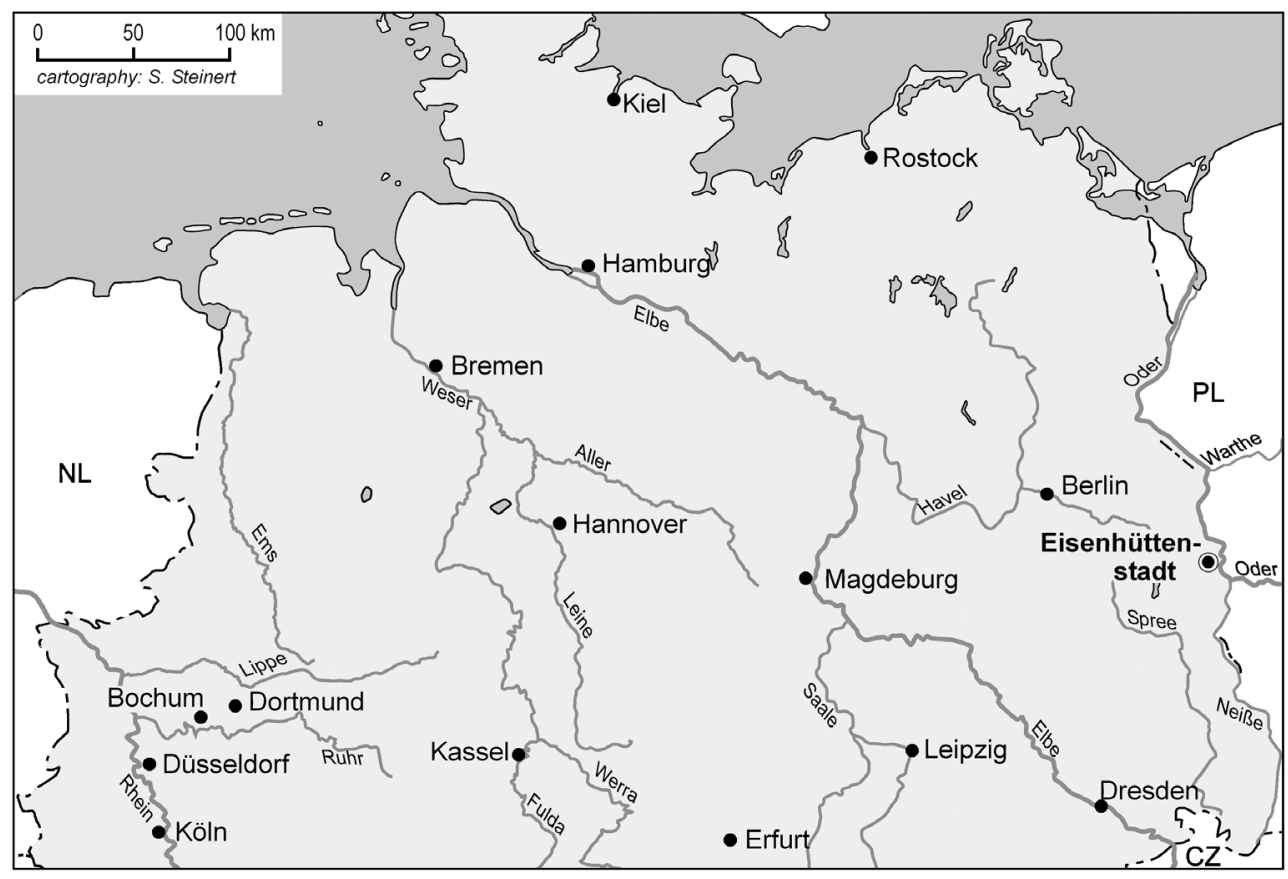

The foundation of Eisenhüttenstadt goes back to a decision by the East German Communist Party from July 1950. The new town was the first to embody the so-called 16 principles for urban development in the GDR. Its site between the village of Schönfließ and the historic town of Fürstenberg (see Fig. 2) was a political choice:

- Its location on the so-called peace-border between Poland and the GDR was to emphasize the brotherhood with Poland, another communist state. "Peace-steel" was to be produced from Russian Ore and Polish coal at a German site.

- The site was big enough for the large iron- and steelworks to be developed. The neighbouring village and small town could provide start-up infrastructure in terms of water, transportation and basic consumer services.

- The works were supposed to provide a major development impulse for the regional economy, creating jobs for the local rural population and for incoming German refugees from eastern Europe. 
The new town grew in step with the EKO ironworks (Eisenhüttenkombinat Ost). The consecutive housing projects I to IV formed the so-called "Stalinstadt" (see Fig. 2), only in 1961 was the city renamed "Eisenhüttenstadt". The housing projects added between 1970 and 1990 (projects V to VII) were built using industrialized construction techniques and standardized, prefabricated components. Eisenhüttenstadt's growth reflected the political and economic importance of steel production in East Germany: as long as the EKO works flourished the city would continue to grow.

Figure 2: Eisenhüttenstadt's urban development

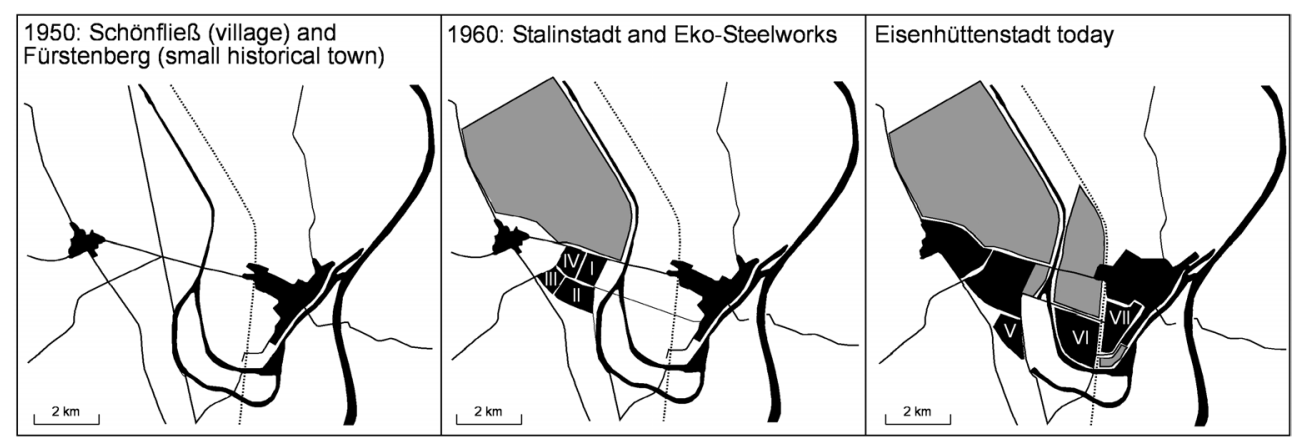

(Howest, adapted by Wieland)

\section{KEY FEATURES OF DECLINE}

\section{A dwindling economy}

After unification of the two Germanies in 1990 the singular dependence on steel production turned out to be the crucial problem for Eisenhüttenstadt. Economic globalization had immediate consequences as the company EKO-Steel - once the largest steel producer in East Germany - was taken over by ARCELOR, a giant European steel producer which already held ARBED in Luxemburg, USINOR in France and ACERALIA in Spain.

In 1989 EKO-Steel had employed 12.000 workers. During 1990 ARCELOR reduced the work force to 2,700 - a loss of 9,300 jobs within one year! Today, EKO-Steel has some 3,000 employees, including subsidiary companies specializing in logistics and transportation. By July 2003, Eisenhüttenstadt's unmeployment rate was at $19.5 \%$ - still one of the lowest in the eastern border regions of Germany.

In the present geography of steel production, the politically motivated locational choice of the Eisenhüttenstadt works proves detrimental, and it is unclear how long modern production technologies and low wages levels may offset its high transportation costs.

\section{Demographic trends}

German unification and the following economic restructuring processes had dramatic impacts on demographic development (see Fig. 3). From 53,000 in 1988, Eisenhüttenstadt's popu- 
lation shrunk to 38,700 in 2002, as many households moved to more western parts of Germany in search of jobs. The loss of 14,300 inhabitants (i.e., $27 \%$ ) within only 15 years is a very harsh fact for a medium sized city! Demographic predictions foresee further decline to 35,000 or even 33,000 inhabitants by 2015 .

These predictions are based on more than just migratory consequences of unification. The birth rate in eastern Germany quickly fell in line with that in the western parts of the united country: at 1.4 per thousand it is now one of the lowest in Europe. Fewer children obviously mean fewer children in the generation to follow, even while life expectancy is predicted to increase. Therefore, Eisenhüttenstadt's population will age as well as shrink.

As a further consequence of German unification - not just in Eisenhüttenstadt - the demand for single family houses increased notably, leading to rapid residential sub- and periurbanization - a trend hitherto virtually unknown in the GDR. Both processes change the spatial and social structures of surrounding villages while leaving behind a substantial number of vacant housing units. This, in turn, threatens the functioning of the local housing market and housing associations, in Eisenhüttenstadt as elsewhere in eastern Germany.

Figure 3: Population: historical development and forecasts

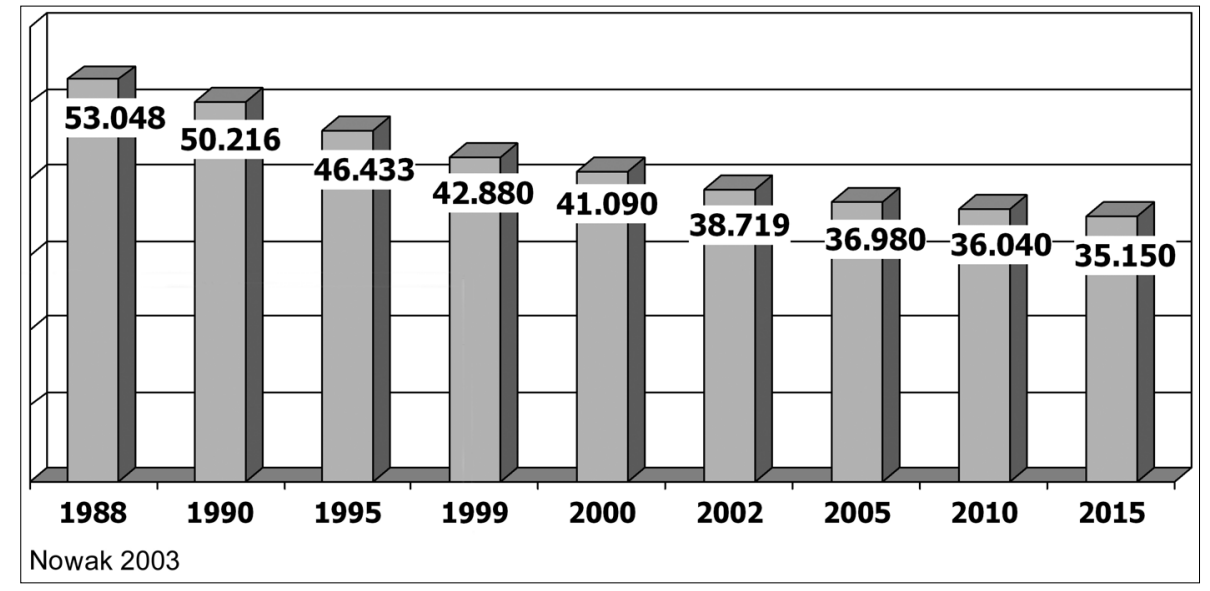

\section{IMPACTS OF DECLINE}

\section{The housing market}

There are only two housing associations in Eisenhüttenstadt: GEWI (Gebäudewirtschaft) has 11,793 housing units and EWG (Eisenhüttenstädter Wohnungsbaugenossenschaft) 6,914 housing units. Of their 18,707 rental flats, 4,340 were vacant in July 2003, giving an average vacancy rate of $23.2 \%$. This is the result of the massive population loss due to outmigration, both to the surrounding coutryside and other, mainly western parts of Germany (see Fig. 4). 
Figure 4: Vacant housing units

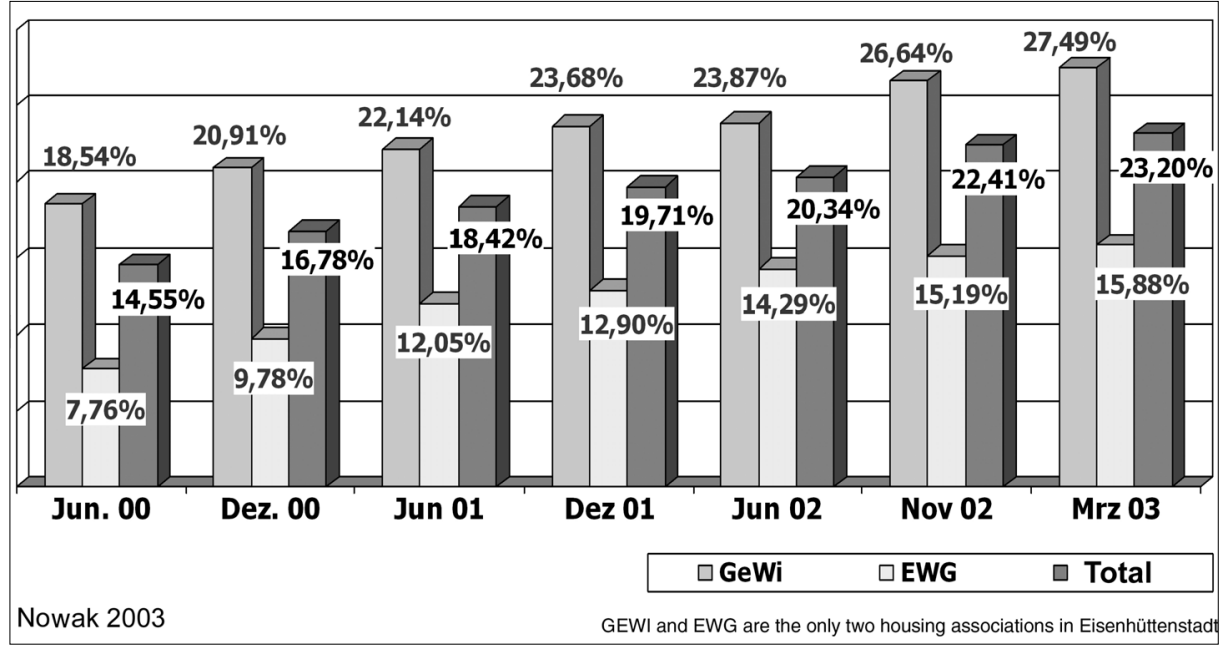

A closer look reveals a differentiated pattern (see Fig. 5). The highest vacancy rates (up to some $60 \%$ in housing project VII South) are found in the newest housing projects in the east. While the housing stock here is only some 15 years old, the quality of the high-rise, prefabricated slab housing (the so-called "Plattenbauten") is as poor as that of the resi-dential environment in general.

Figure 5:Vacant housing units per housing project 2003

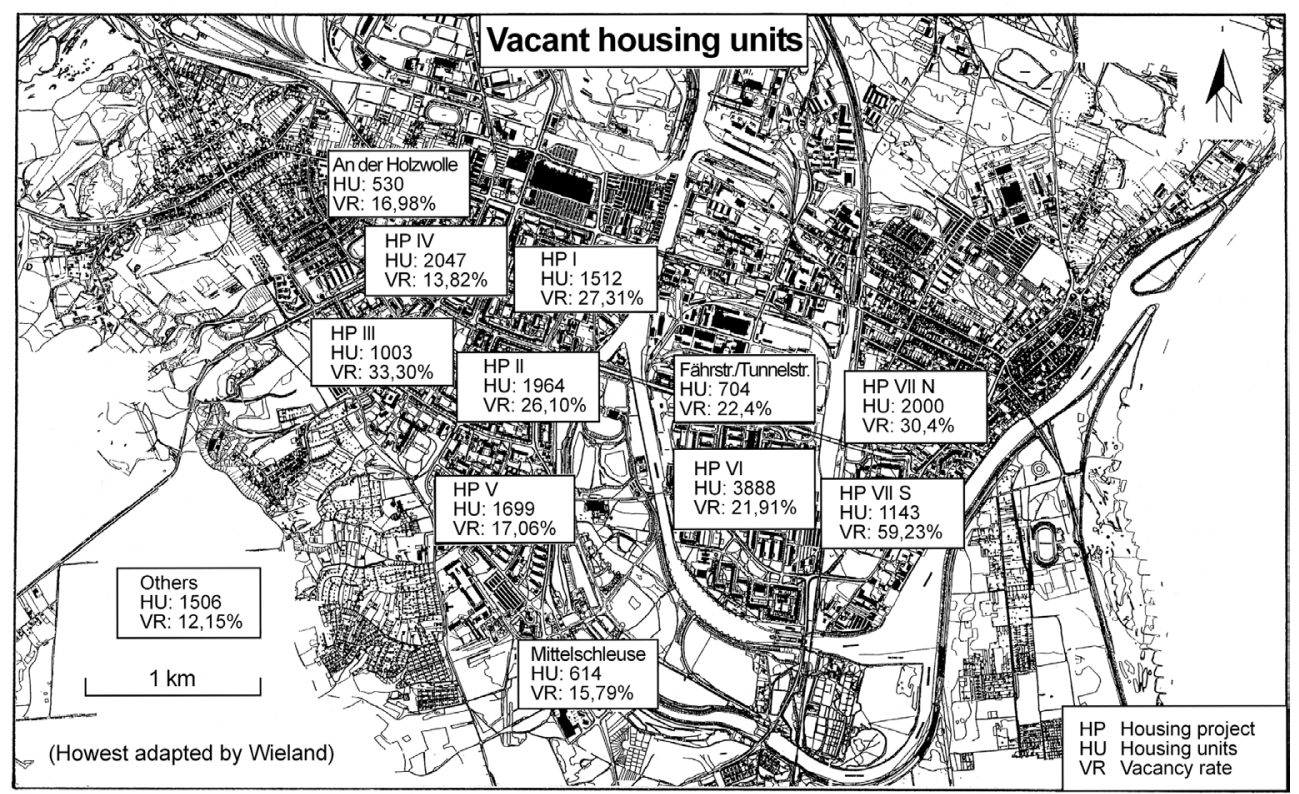




\section{Retailing}

Obviously population decline strongly interacts with a shrinking economy. Retailing acts as a good indicator of such processes. Mappings of retail businesses in the historic center of Fürstenberg revealed clear signs of an ongoing process of decline. Shops and houses were often in poor condition and vacancies are increasing (13 in 2002, a few more expected by the end of 2003). The loss of attractiveness and importance is also very visible in the town centre of Eisenhüttenstadt itself.

However, these processes are not only the result of economic and demographic decline but also of contemporary trends in retailing. The term "Americanization" is often employed to describe the emergence of big box stores and hypermarkets in three distinct retailing centres, mostly targeting the low end price segments of the market.

\section{POLICY RESPONSES}

\section{The role of the federal state}

The transformation process in the former GDR is still accompanied by severe social, ecological and economic problems, which reveal their impacts at the local level, e.g. through the decline of many urban districts. Outmigration has resulted in 1 million vacant housing units and triggered a self-propelling process of further economic, social and urban decline. Population decline and social polarization are becoming most obvious in the high-rise slab housing projects („Plattensiedlungen“) built between 1960 and 1990 and in the old inner city districts.

The programme „Stadtumbau Ost“ („Restructuring cities in the East") was launched by the federal government in 2002. Its aim is to strengthen the urban and economic fabric of towns and cities in the former GDR and to make them more attractive for residents and investors. The federal government, the state governments and the municipalities will join forces to pay subsidies amounting to 2.5 billion $€$ for the demolition of vacant buildings and for revitalizing mainly inner city districts. Federal funds depend on state governments and municipalities each contributing $33 \%$ of total project costs. The policy works through a competition involving 261 selected urban municipalities. These have to develop an urban planning and development strategy in order to compete, and if successful they will receive subsidies. „Stadtumbau Ost“ is a programme to physically rebuild the cities, it is not based on an integrative physical-social approach, like the one used by the joint federal-state programme „Stadtteile mit besonderem Entwicklungsbedarf: Die soziale Stadt“.

\section{The approach of Eisenhüttenstadt}

Given its multitude of problems of decline, in September 2002 Eisenhüttenstadt developed an urban planning and development strategy to compete for funds from the "Stadtumbau Ost" programme. Being successful in the bid, the city will now receive two types of subsidy from the programme: a flat rate for the demolition of buildings ( $€ 60$ per ) and a lump 
sum for physically improving inner city districts. The municipality needs to provide one third of project costs, the other two thirds are financed by the federal government and the state of Brandenburg.

These subsidies form a political watershed. Up to 2000 subsidies were always paid for new construction, not for the destruction of existing housing. Furthermore, any funds for the physical and social improvement of urban areas were very hard to come by. There is no doubt, that Eisenhüttenstadt's restructuring needs are urgent, taking into consideration its severe economic and urban development problems. However, given the severe fiscal crisis of pretty much all German municipalities, it remains doubtful whether Eisenhüttenstadt can even afford its $33 \%$ share of total project costs as the programme demands.

\section{Economic development strategy}

Within a market economy, the state's influence on private economic decisions are very limited, indeed. All the same, the City of Eisenhüttenstadt has developed a general economic development strategy with the following corner stones:

- Strengthening Eisenhüttenstadt as a location for steel production by specializing on niche products and by supporting recycling-based industries

- Diversifying the city's economic base

- Improving the city's infrastructure, in particular by reconstructing the pre-war bridge over the river Oder, to encourage transborder activities (thus anticipating the enlargement of the European Union)

\section{Urban development strategy}

Eisenhüttenstadt's application to the „Stadtumbau Ost“ programme earmarked five housing projects for demolition and restructuring. Interestingly, these are the most recent housing projects of the GDR, only built shortly before unification in 1990. The planning department used several criteria to select these housing projects:

- urban design criteria

- $\quad$ overall municipal land-use planning goals

- $\quad$ vacancies within the housing stock

- environmental quality

- $\quad$ physical infrastructure

The municipality considers housing vacancies and physical infrastructure to be the most important criteria for targeting housing projects for demolition. The underlying rationale is an engineering one: Infrastructure provisions for each housing project were based on a population of 3,000 inhabitants. Whenever at least $30 \%$ of housing units are vacant or demolished, the sewage system will experience flushing problems, causing frequent and costly cleaning operations. Likewise, maintenance costs for transportation infrastructure will increase per head. Therefore the municipality attempts to target complete housing projects for demolition rather than individual apartment blocks here and there.

Eisenhüttenstadt's planning department expects as many as 5,800 vacant housing units by 2015 - which amounts to nearly one third of the total stock of the city's housing associations (see Fig. 4, 5 and 6)! Given some safety margins, the department predicts that 3,500 flats will have to be demolished to avoid the emergence of a "ghost town" situation. 
flats will have to be demolished to avoid the emergence of a "ghost town" situation. Eisenhüttenstadt's administration plans to demolish whole housing projects due to the above-mentioned civil engineering problems. Plans are to demolish 1,965 flats within housing projects VII (North and South) and Fährstraße/Tunnelstraße up until 2007 (see Fig. 5). 1,335 more flats should be demolished between 2008 and 2010, mainly in the most recent GDR housing projects with their high-rise slab buildings.

Figure 6: Housing market forecasts for 2015

\begin{tabular}{|ll|}
\hline $\begin{array}{l}\text { Expected vacancies in 2015 } \\
\text { (estimate: 5,300 - 5,800 HU) }\end{array}$ & $\mathbf{5 , 8 0 0 ~ H U}$ \\
Change of use, disuse & $300 \mathrm{HU}$ \\
Merging HU to form bigger units & $450 \mathrm{HU}$ \\
Reserve to accommodate & \\
forecast uncertainties & $1,550 \mathrm{HU}$ \\
Total reductions & $2,300 \mathrm{HU}$ \\
Demolition & $\mathbf{3 , 5 0 0 ~ H U}$ \\
(Adapted from Nowak 2003) & \\
\hline (HU= housing units) &
\end{tabular}

With demolition will arise new brownfield problems which are as yet unresolved. The city sees several options:

- Do nothing and let nature re-colonize the sites - an approach used for many former industrial sites in the Ruhr

- Redevelop the sites for leisure facilities which are in short supply in Eisenhüttenstadt

- Allocate allotment gardens close to the remaining housing units

- Redevelop the sites for single family homes taking advantage of existing infrastructure

Of course, Eisenhüttenstadt will not only experience demolition. Albeit modest, there are also initiatives of urban revitalization and renewal, especially regarding the provision of infrastructure and public services, e.g., the refurbishment of day care centres or the renovation of public buildings. The municipality's priority, however, will be to avoid the emer-gence of a sad and desolate "ghost town".

\section{SUMMARY AND CONCLUSION}

In the western parts of Germany cities will be increasingly divided into two categories: prospering cities on the one hand, stagnating or declining cities on the other. The latter will also experience negative population growth (cf. my paper at the Pretoria meeting, 2002). In eastern Germany virtually all cities - like Eisenhüttenstadt - will fall into this second category. Since the economic and demographic aspects of decline are interlinked and feed off one another, a viscious cycle emerges which becomes particularly visible in the crises experienced by local retailing businesses. 
Inspite of severely changing reproductive behaviour in eastern Germany, the central element of demographic change in its cities is a negative migration balance. This net loss of population has economic reasons, with people migrating to more prosperous regions, but it is also fuelled by an ongoing process of suburbanization, driven by a continuous demand for new single family housing. Yet such declining cities do not shrink in space even when they experience significant population losses. Therefore, they experience a reduction of average population densities leading to increasing per capita costs for the maintenance of infrastructure, at the same time as increasing vacancies threaten the functioning of the local housing market.

The "Stadtumbau Ost" programme intends to tackle these problems of decline. Its goals are to strengthen the urban and economic fabric of towns and cities in the East to make them more attractive for residents and investors as well as to subsidize the demolition of vacant buildings and the physical revitalization of inner city districts.

The municipality of Eisenhüttenstadt is very concerned about its massive population losses and hopes to avoid the emergence of a "ghost town" situation. It has applied for and been granted funds from the "Stadtumbau Ost" programme, based on a strategy which focusses demolition efforts on the city's most deprived housing projects. This spatial concentration of measures is an outcome of engineering problems related to sewage and public transport systems. However, even when demolition is "successful", it will leave the city with a number of new brownfield sites. While these may be seen as a chance for future urban development, opportunities strongly depend on at least modest economic revival which would result in investment and diversification of the labour market.

Some concluding theses can highlight the severity of the problems in many eastern German towns and cities:

- Demolition of substantial portions of the housing stock will form the only possible strategy to avoid the appearance of "ghost towns" in many cities of eastern Germany.

- The enormous dimensions of population decline leaves cash-strapped municipalities with no fiscal leeway to tackle these problems on their own. Substantial financial help from senior levels of government is urgently required.

- The subsidies awarded by the "Stadtumbau Ost" programme are insufficient to have significant effects. If Eisenhüttenstadt housing associations have to service debts of $70 €$ per $\mathrm{m}^{2}$, demolition subsidies of $60 €$ per $\mathrm{m}^{2}$ may well prove insufficient.

- The fiscal crisis of German municipalities renders co-financed programmes like "Stadtumbau Ost" ineffective, since few municipalities are able to raise the required matching funds.

- This may lead to widespread inertia and accelerating physical and social degradation. Without substantial planning efforts and the appropriate funding, deterioration of the housing stock will lead to processes of slum formation hitherto unknown in the German context.

- Government policy is contradictory and thus far from effective. Various government policies subsidize the continuing suburbanization of households. Home ownership subsidies paid for the construction of new homes and tax allowances for commuting costs counteract any measures aimed at the strengthening of urban centres and the maintenance 
of existing infrastructure and housing stock. Canceling such subsidies would be more beneficial for urban development and restructuring than any new emergency programme.

\section{Literature}

Bundesamt für Bauwesen und Raumordnung (BBR) (ed.), 2000: Urban Development and Urban Policy in Germany. An Overview. Berichte Vol. 6. Bonn, Bundesamt für Bauwesen und Raumordnung.

Bundesministerium für Verkehr, Bau- und Wohnungswesen (BMVBW) and Bundesamt für Bauwesen und Raumordnung (BBR) (eds.), 2002: Fachdokumentation zum Bundeswettbewerb „Stadtumbau Ost“. Bonn, Bundesministerium für Verkehr, Bau- und Wohnungswesen.

Bundesministerium für Verkehr, Bau- und Wohnungswesen (BMVBW) and Bundesministerium für Wirtschaftliche Zusammenarbeit und Entwicklung (BMWZE) (edits.), 2001: Auf dem Weg zu einer nachhaltigen Siedlungsentwicklung. Nationalbericht der Bundesrepublik Deutschland. Berlin, Bundesamt für Bauwesen und Raumordnung.

Bundesministerium für Verkehr, Bau- und Wohnungswesen (BMVBW) (ed.), 2001: Stadtumbau in den neuen Ländern. Integrierte wohnungswirtschaftliche und städtebauliche Konzepte zur Gestaltung des Strukturwandels auf dem Wohnungsmarkt der neuen Länder. Bonn, Bundesamt für Bauwesen und Raumordnung.

Eisenhüttenstädter Gebäudewirtschaft GmbH (ed.), 2000: Die Planstadt. Eisenhüttenstadt. Die Wohnkomplexe I-IV. Geschichte, Architektur, Sanierung, Modernisierung. Eisenhüttenstadt.

Lötscher, L. and Schmitz, S., 2001: Der beschwerliche Weg zu einer nachhaltigen Stadtentwicklung. Berichte zur deutschen Landeskunde 75 (2/3), 333-342.

Lötscher, L. (in print). Monitoring German Cities of Tomorrow: Challenges and Perspectives. In: Proceedings of the Pretoria Conference 2002, IGU Urban Commission C 19. Monitoring Cities of Tomorrow.

Nowak, C., 2003: Stadtumbau Ost. Presentation during the workshop of the "Stadtzukünfte" (urban futures) working group of the German Society for Geography, April 26, 2003, Eisenhüttenstadt.

Wiegandt, C-C., 2000: Urban development in Germany - perspectives for the future. In: GeoJournal 50, 51-55. 